\title{
sciendo
}

\section{TYPOLOGY OF THE ALBANIAN SMALL-SCALE FISHERIES}

\author{
Rigers Bakiu ${ }^{1}$, Dimitrios K. Moutopoulos ${ }^{2 *}$, Marthjon Gurma ${ }^{1}$, Marko Çakalli ${ }^{1}$
}

${ }^{1}$ Department of Aquaculture and Fisheries, Faculty of Agriculture and Environment, Agricultural University of Tirana, Tirana, Albania

${ }^{2}$ Department of Animal Production, Fisheries \& Aquaculture, University of Patras, Mesolongi, Greece

*Corresponding author: dmoutopo@upatras.gr

\section{ARTICLE INFO}

Received: 20 April 2021

Accepted: 25 October 2021

\begin{abstract}
The lack of reliable fisheries statistics hampers full assessment of the status of marine resources. Central to this problem are data-poor fisheries such as the Albanian seas and in particular the SSF sector. The present study aims to portray the small-scale fishery of south Albanian waters based on daily onboard monitoring of fisheries species catches during a two-year period (2016-2018). Results revealed a total of 6 and 11 fishing métiers for the nets and longlines, respectively. The most important target species for nets in terms of catches were Merluccius merluccius, Mullus surmuletus, Pagellus erythrinus, Sepia officinalis and Solea vulgaris. Longline fisheries were categorized into two distinct fishing métiers, one targeting the large pelagics Thunnus thynnus and Xiphias gladius, and the other targeting a wide range of Sparidae species and Epinephelus marginatus. The data and analysis presented here aim to reduce the current lack of quantitative data on a fisheries data-limited case such as the Albanian small-scale fishery and to provide information for developing monitoring for this fishery.
\end{abstract}

Bakiu, R., Moutopoulos, D. K., Gurma, M., Çakalli, M. (2022). Typology of the Albanian small-scale fisheries. Croatian Journal of Fisheries, 80, 26-37. 1. DOI: $10.2478 /$ cjf-2022-0004. 


\section{INTRODUCTION}

Worldwide, there is a continued requirement for the collection of scientific data from commercial fishing trips, and the monitoring of the fisheries resources represents one of the basic pillars of the European fisheries management (STECF, 2016). With the recent Technical Measure Regulation in mind and the protection of sensitive species (EU REG 1241/2019), there is a need to develop a more comprehensive methodology to further evaluate and assess the impacts of fisheries on these species. The European Data Collection Framework (DCF, Reg 199/2008 and 665/2008) put emphasis on the shift from singlespecies population approach to the ecosystem-based ones (Urlich et al., 2012) under the métier-based approach. The latter defines a group of similar exploitation patterns targeting similar species and using similar gear in similar periods of the year within similar areas. The definition of fishing tactics, of target and incidentally caught species (i.e. the landings of all non-target species) might be useful for evaluating the current sampling stratification schemes for the industrial and small-scale fisheries (SSFs) (Maynou et al., 2011).

SSFs follow the heterogeneity of the ecosystem, showing a vast array of fishing gear that operates in different seasons and fishing grounds while targeting a large number of species (Lloret et al., 2018). The impact of each of the above-mentioned fishery compartments on fisheries stocks remains unknown, as this is inherently difficult to monitor (FAO, 2020). The problem gets more complicated when taking into account that the Mediterranean smallscale fishing vessels of a length size under 12 meters are not subject to the obligation to transmit fishing logbooks (EU REG 404/2011). The above issues have led to unquantifiable bias in the SSFs data, which hampers a full assessment of the status of marine fisheries. Central to this problem is the lack of reliable catch statistics, which is used as a core input into stock assessments. This is the main issue for fisheries data-poor areas such as the Albanian seas and in particular its SSFs sector.

Although SSFs have been thoroughly examined in different parts of the Mediterranean (Spain: Maynou et al., 2011; Tunisie: Jabeur et al., 2000; Greece: Tzanatos et al., 2020), including the Adriatic Sea (Carpi et al., 2017; Matić-Skoko et al., 2017; Grati et al., 2018), however, none of the studies have treated SSFs in Albanian waters. SSFs in Albanian waters contributed slightly more than $5 \%$ of the total fisheries (Ministry of Agriculture and Rural Development, 2019). Its contribution is higher in the southern parts of Albania's Exclusive Economic Zone due to rocky seabed deep waters, when compared with the northern parts that include an extensive easy-to-trawl shelf (Çobani, 2005; Bakiu and Gurma, 2018; Bakiu et al., 2018).

Two different approaches are implemented to identify métiers; input-based (technical information on the fishing trip, e.g. gear, area, season) and output-based (building on the outcomes of the trip, i.e. what was caught). Inputbased approaches are based on interviews with skippers or logbooks, whereas output-based ones rely on the level of the individual vessel trip and are based on species catch data caught during a fishing trip (Urlich et al., 2012). In the present study, information of fishing trip specificities and species catch data derived from onboard observations were used to portray SSFs in Albanian waters (South Adriatic). The effort was also focused on the description of the species composition of the target and incidental species caught by the corresponding fisheries, including the identification of different fishing tactics used. The high-frequency monitoring facilitates the identification of alternative fishing tactics during short-term periods in case the fishermen take advantage of the feeding, reproductive behavior and market demands.

\section{MATERIALS AND METHODS}

\section{Study area}

South Albania area (Fig. 1) is represented by the Sarandë and Himara regions. Sarandë is a region of 11,257 inhabitants and it is approximately $20 \mathrm{~km}$ long and $5 \mathrm{~km}$ wide, bounded by the $2000 \mathrm{~m}$ high Llogara Mountains to the northeast and the Ionian Sea to the southwest. The Himara Region is a popular touristic destination during summer, which creates a high demand for fish. Furthermore, the coastal area is famous for marine biodiversity, represented by teleosts, sharks, rays and skates, which are mainly fished by trawlers.

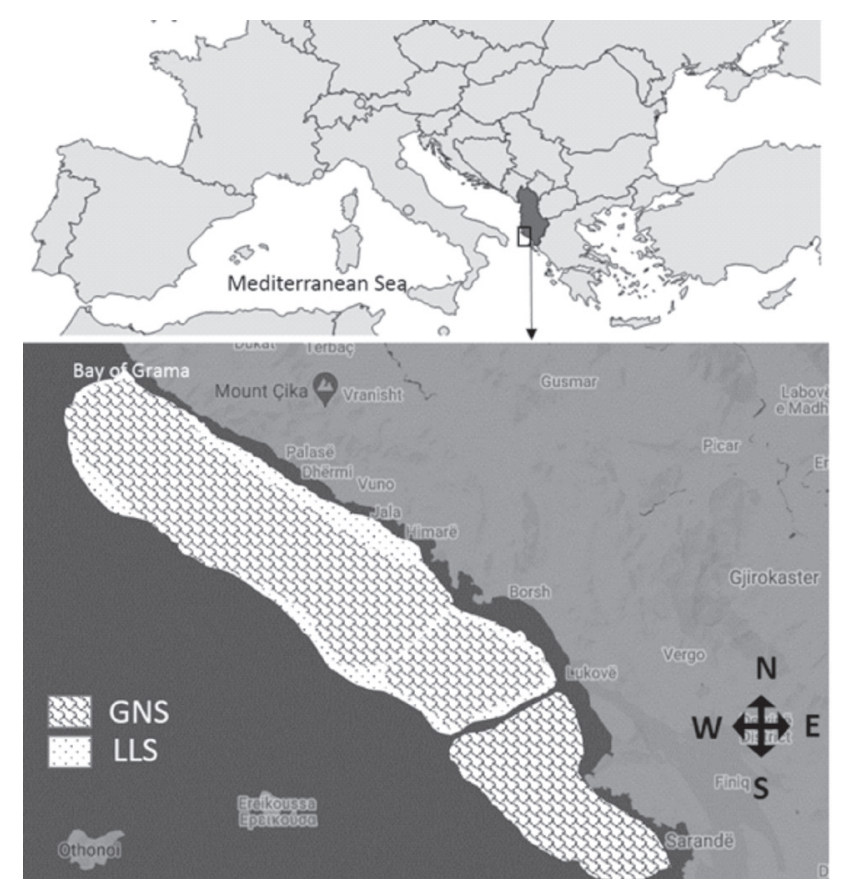

Fig 1. Map showing the location of southern Albanian waters and the sampling sites for gillnets (GNS) and set longlines (LLS) 
More than half of the total Albanian fishing fleet (564 fishing vessels) consists of small-scale vessels (61\%) with the estimated percentage of employment of about $28 \%$ of the total employment in the Albanian fisheries sector (FAO, 2020). Sarandë is the third biggest fishing port in Albania in terms of the number of small-scale vessels. A considerable number of these vessels in Albanian waters is located there (36 out of 345 fishing vessels, 16\%), with length less than $12 \mathrm{~m}$, mostly using nets and longlines (Bakiu and Gurma, 2018). The Dock of Himara hosts five small-scale vessels with a length of less than $12 \mathrm{~m}$ (with the engine). The main fishing equipment is represented by pelagic longlines and fixed nets (mainly trammel nets). The average engine power of these fishing vessels is $100 \mathrm{HP}$, though recently the tendency is toward a higher engine power per fishing vessel. SSFs in the studied areas

Table 1. Species composition per fishery. Bold values indicated the species contributed up to $80 \%$ of the species catch (in $\mathrm{kg}$ ) and value (in $€ / \mathrm{kg}$ ) composition per each fishery (GNS, nets and LLS, longlines) in the south Albanian waters, during 2016-2018.

\begin{tabular}{|c|c|c|c|c|c|}
\hline \multirow{2}{*}{ Species } & \multicolumn{3}{|c|}{ Catch (kg) } & \multicolumn{2}{|c|}{ Economic value } \\
\hline & GNS & LLS & Total & Total $€$ & $€ / \mathrm{kg}$ \\
\hline Boops boops & 380.0 & & 380.0 & 1.6 & 611.8 \\
\hline Dentex dentex & 34.0 & & 34.0 & 10.8 & 365.5 \\
\hline Dicentrarchus labrax & 43.4 & & 43.4 & 10.5 & 454.8 \\
\hline Diplodus cervinus & & 106.2 & 106.2 & 12.1 & 1285.0 \\
\hline Diplodus sargus & 109.1 & 281.3 & 390.4 & 15.3 & 5980.9 \\
\hline Epinephelus marginatus & 81.5 & 241.5 & 323.0 & 12.9 & 4166.7 \\
\hline Homarus gammarus & 2.1 & & 2.1 & 45.7 & 96.0 \\
\hline Loligo vulgaris & 38.1 & & 38.1 & 7.3 & 276.6 \\
\hline Merluccius merluccius & 3757.4 & & 3757.4 & 5.4 & 20214.8 \\
\hline Mugil cephalus & 310.0 & & 310.0 & 4.8 & 1500.4 \\
\hline Mullus surmuletus & 743.4 & & 743.4 & 7.8 & 5798.5 \\
\hline Oblada melanura & 112 & & 112.0 & 2.4 & 271.0 \\
\hline Octopus vulgaris & 226.3 & & 226.3 & 5.1 & 1154.1 \\
\hline Pagellus erithrynus & 1365.0 & & 1365 & 25.8 & 8747.0 \\
\hline Pagrus pagrus & & 338.9 & 338.9 & 25.8 & 316.3 \\
\hline Sarpa salpa & 156.6 & & 156.6 & 2.0 & 158.9 \\
\hline Scomber scombrus & 196.2 & & 196.2 & 0.8 & 370.3 \\
\hline Scophthalmus rhombus & 30.6 & & 30.6 & 12.1 & 579.1 \\
\hline Scorpaena scrofa & 239.3 & & 239.3 & 2.4 & 466.5 \\
\hline Sepia officinalis & 77.1 & & 77.1 & 6.0 & 1752.6 \\
\hline Seriola dumerili & 310.2 & & 310.2 & 5.6 & 164.2 \\
\hline Siganus luridus & 67.86 & & 67.86 & 2.4 & 325.2 \\
\hline Solea solea & 67.2 & & 67.2 & 4.8 & 434.8 \\
\hline Sparisoma cretense & 107.9 & & 107.9 & 4.0 & 2907.2 \\
\hline Sparus aurata & 56.7 & 220.7 & 277.4 & 10.5 & 1813.7 \\
\hline Sphyraena sphyraena & 321.0 & & 321.0 & 5.6 & 13498.2 \\
\hline Thunnus thynnus & & 1288.0 & 1288.0 & 10.5 & 94.0 \\
\hline Trachurus trachurus & 58.4 & & 58.4 & 1.6 & 3194.4 \\
\hline Trigla lyra & 440.0 & & 440.0 & 7.3 & 34998.0 \\
\hline Xiplias gladius & 100.0 & 4032.0 & 4132.0 & 8.5 & 35230.7 \\
\hline Total catch (kg) & 9431.4 & 6508.6 & 15940 & & \\
\hline Total value $(€)$ & 79808.3 & 67419.1 & & & 147227.4 \\
\hline
\end{tabular}


is targeting swordfish Xiphias gladius, Atlantic bluefin tuna Thunnus thynnus, European hake Merluccius merluccius and striped red mullet Mullus surmuletus, which are the most preferred species in the improvised fish market located inside the Himara Dock, in the Himara Region.

\section{Fishing sampling}

Sampling took place with commercial small-scale fishing vessels of lengths ranging from $3.5 \mathrm{~m}$ to $15 \mathrm{~m}$ and engine horsepower from 15 to 380 . Sampling design covered more than $1 / 4$ of the number of small-scale vessels operating in south Albanian waters (11 out of 41 vessels) between Grame (Vlora), Porto Palermo (Himara) and close to Sarandë, at depths up to $400 \mathrm{~m}$. Most of the fishing operations are performed close to the Bay of Sarandë (Manastir, Kakome, Qefal, Lukov, Borsh), while the remaining ones close to Himara. They lasted from 2 to 15 hours.

For net samplings (seven vessels sampled), port surveys were performed 3 times per month from July 2016 to March 2017 (22 fishing days sampled) in Sarandë Port, and 2 times per month from August 2016 to September 2018 (71 fishing days sampled) in Himara Port, and totally covered 86 different fishing days. Nets deployed are mostly fixed multifilament/monofilament white/ transparent, with lengths ranging from 1200 to $3000 \mathrm{~m}$ and mesh size of the net between 22 and $30 \mathrm{~mm}$ (knot to knot). The setting of the nets is generally conducted in the evening and hauling before dawn. For longline sampling (four vessels sampled), surveys were performed at least 3 times per month (if weather conditions permitted) from July 2016 till March 2017 (160 fishing days sampled). Longlines used had lengths ranging from 3800 to 10000 $\mathrm{m}$ and hook numbers from No 3 (drifters) to No 13 (set longlines) with multifilament transparent fiber. They were deployed during the day and were baited with squids or sardines.

The fishing grounds were selected by the professional fishers in traditional areas in order to ensure the highest possible catches and that fishing was as similar as possible to the traditional fishing activities employed in each site. One to three scientists accompanied the professional fishers in order to separate the catches and record the required information. Standard fishing practices were followed by setting the gear 1-2 hours before sunrise or sunset, and hauling 1-2 hours after sunrise or sunset. After hauling, the catch was removed and separated by hook and mesh size.

\section{Data analyses}

Overall 218 fishing trips that were relative to a fishing trip were described by 12 variables which were constructed in a matrix of 184 lines and 12 columns. The variables were vessel name, date, gear used, gear length and mesh size and the number of hooks, vessel length and engine power (in horsepower), fishing depth, and time and species caught per $\mathrm{kg}$. Data used for identifying fishing tactics and strategies are based on catch compositions, which are considered by a matrix of species catches and values, and fishing units that are considered as a set of choices, which are identified by each vessel per fishing trial. Taking into account that vessel characteristics (i.e. vessel length and engine power) and gear specifications (i.e. length and mesh size used) are constant for each fishing vessel, therefore, fishing tactics are determined by the combination of a fishing vessel, depth, fishing time duration and date. Each element of such a set corresponds to a tactic given to a multi-species composition, such as the Mediterranean ones, and the target species must: (a) be representative of a single métier; (b) have large total landings or very high market value; (c) consist of more than $50 \%$ of the overall landings.

Clustering methods have been frequently applied to identify groups of homogeneous groups that describe métiers in terms of catch composition per area, fishing gear and technical characteristics of the gear used (i.e. length and type of the gear, fishing duration) (e.g. Celtic Sea: Moore et al., 2019; North Sea: Deporte et al., 2012; West Mediterranean Sea: Maynou et al., 2011, 2013; East Mediterranean Sea: Moutopoulos et al., 2014). Target species have been identified as the species that contribute the highest percentage of similarity in the formation of the major groups.

For that, cluster analyses were used by applying on two matrices (rows $X$ columns), each for a gear used, nets and longlines: species composition $X$ sampling trials. Species catch composition matrices were squared-transformed in order to reduce the weighting of abundant or valuable species (Field et al., 1982) by retaining as many species as possible to maintain the multi-species features of the Mediterranean SSFs. Then, matrices were both converted into triangular matrices of similarities using the Bray-Curtis coefficient (Bray and Curtis, 1957) and were subjected to the group-average linking method. Differences between the identified groups formed by the cluster analysis are based on centroid distances between groups, which were tested with the non-parametric PERMANOVA test (Anderson et al., 2008). Pair-wise comparisons were computed when significant differences $(p<0.05)$ were detected among factor levels.

The contribution of each species to the average BrayCurtis similarity within the aforementioned groups was also identified using SIMPER analysis (Clarke and Warwick, 2001). The proportion of species in each fishing tactic (cluster) was also estimated. Cumulative monthly dominance curves were also plotted for the most important groups formatted by the multivariate analysis in terms of catches based on catchweight. Dominance curves show the percentage cumulative weighted abundance against log species rank (Clarke and Warwick, 2001). All the above-mentioned multivariate analyses were performed using PRIMER ver 6 \& PERMANOVA+ (Anderson et al., 
2008). Finally, mean annual values (in $€$, transformed by LEC) per kg for all species caught were taken from fish stores in Sarandë center, and the economic return per fishing tactic (=fishing trials) was also estimated for each fishery (i.e. nets and longlines).

\section{RESULTS}

\section{Catch and species composition}

Overall, 86 fishing days were sampled with nets and 160 with longlines. Overall, $15940 \mathrm{~kg}$ of specimens were measured belonging to 30 species ( 26 fish species, one crustacean species and three cephalopod species) (Table 1). Fishes made up the major part both for the catch and economic value for all gear combined (>96.4\%), and nets contributed more than longlines to the total catch and economic revenue (> 54.2\%). Catch species composition differed with gear type (Table 1); nets exhibited a multi-species character with 8 species contributing approximately $80.9 \%$ and $87.9 \%$ of the total catch and value, respectively (indicated by bold values in Table 1), with the remaining percentage being covered by 19 species. In contrast, longlines caught a total of 7 species with two of them (i.e. Thunnus thynnus and Xiphias gladius) cumulatively contributing $81.7 \%$ and $70.7 \%$ of the catches and value, respectively.

\section{Métier identification}

For the nets, the classification of the matrix applied on the catch species compositions per fishing trials indicated that, at the $61.84 \%$ similarity level, sampling trials significantly (PERMANOVA test: pseudo F-ratio = 32.30; $p<0.05)$ grouped into six groups of fishing trials (Table 2), complemented by six fishing trials that were grouped into the according number of outliers. For the longlines, the classification of the matrix applied on the catch species compositions per fishing trial indicated that, at the $67.34 \%$ similarity level, the sampling trials were significantly (PERMANOVA test: pseudo F-ratio $=58.45 ; p$ $<0.05$ ) grouped into 11 groups of trials (Table 2 ), whereas one fishing trial was grouped separately as an outlier.

For the nets, Groups C and D comprised high catch and income métiers with intense fishing activity (64\% of the total fishing trials made by nets) that made $82.7 \%$ and $88.2 \%$ of the total SSFs catches and revenue (Tables 2, 3, 4). These groups were seasonally extending throughout the year, from February to November apart from August, and peaked during spring ( $40.7 \%$ and $71.3 \%$, respectively) (Fig. 2).

They were operated in shallow waters up to $400 \mathrm{~m}$ (Table 4), using mesh sizes of nets ranging from 22 to $36 \mathrm{~mm}$. Group C did not exhibit any species-specific métier with the majority of the catches $(>80.1 \%$ ) and was represented by 8 species (i.e. Merluccius merluccius, Pagellus erythrinus,

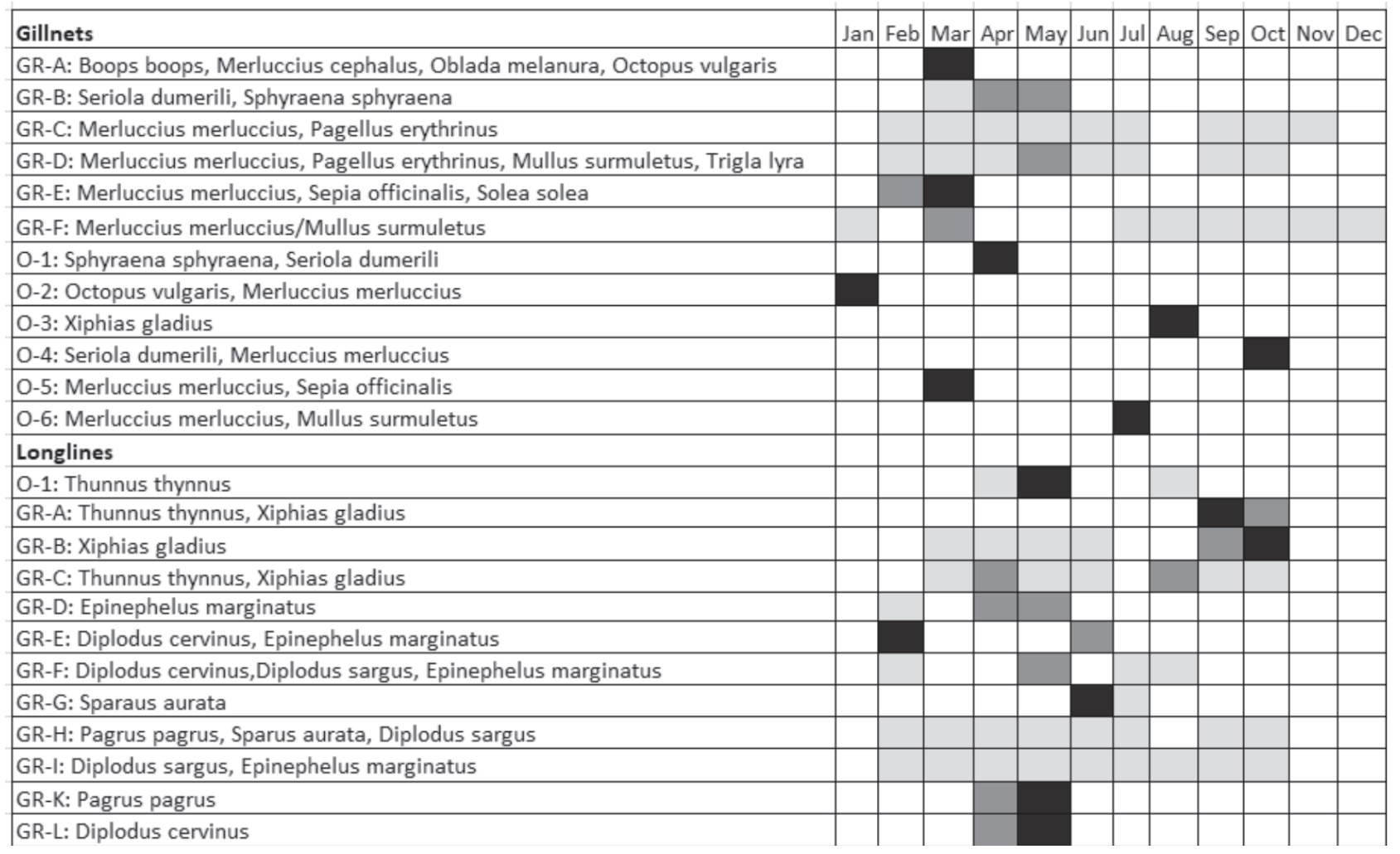

Fig 2. Fishing period of each métier for nets (GNS) and longlines (LLS) in south Albanian waters corresponds to the grey shading; no shading: no catch; light grey shading: between $0 \%$ and $25 \%$; dark grey shading: between $25 \%$ and $50 \%$; black shading: more than $50 \%$ 
Table 2. Nets. Contribution (\%) to the average Bray-Curtis similarity of the SIMPER analysis and species catch composition (\%) identified by the multivariate analysis on the species catch composition per fishing trials in the south Albanian waters, $2016-2018$. Total catch (in $\mathrm{kg}$ ) and economic return (in €) was also provided per group. Bold values indicated the highest catch and economic values per group.

\begin{tabular}{|c|c|c|c|c|c|c|c|c|c|c|c|c|}
\hline Nets & GrA & GrB & $\mathrm{GrC}$ & GrD & GrE & GrF & Out 1 & Out 2 & Out 3 & Out 4 & Out 5 & Out 6 \\
\hline SIMBER analysis & $73.7 \%$ & $67.8 \%$ & $76.5 \%$ & $84.8 \%$ & $68.5 \%$ & $62.1 \%$ & & & & & & \\
\hline Boops boops & 13.0 & 10.4 & 6.0 & & & & & & & & & \\
\hline Dentex dentex & & & & & & 6.7 & & & & & & \\
\hline Diplodus sargus & & 6.7 & 3.6 & & & & & & & & & \\
\hline Merluccius merluccius & & & 22.4 & 41.5 & 23.5 & 50.8 & & & & & & \\
\hline Mugil cephalus & 19.5 & 7.8 & 4.0 & & & & & & & & & \\
\hline Mullus surmuletus & 5.9 & 7.2 & 7.7 & 16.9 & 14.1 & 20.9 & & & & & & \\
\hline Oblada melanura & 7.4 & & 3.4 & & & & & & & & & \\
\hline Octopus vulgaris & 11.8 & & 4.6 & & 10.3 & & & & & & & \\
\hline Pagellus erithrynus & & & 13.4 & 22.7 & & & & & & & & \\
\hline Sarpa salpa & 10.1 & 5.9 & 3.9 & & & & & & & & & \\
\hline Sepia officinalis & & & & & 14.0 & & & & & & & \\
\hline Seriola dumerili & & 15.7 & & & & & & & & & & \\
\hline Solea solea & & & & & 16.6 & 14.3 & & & & & & \\
\hline Sphyraena sphyraena & & 14.6 & & & & & & & & & & \\
\hline Trachurus trachurus & & & & & 14.0 & & & & & & & \\
\hline Trigla lyra & & & 4.5 & 11.5 & & & & & & & & \\
\hline \multicolumn{13}{|l|}{ Species composition } \\
\hline Boops boops & 21.3 & 13.2 & 4.4 & & & & & & & & & \\
\hline Dentex dentex & & & 0.1 & 0.2 & 4.4 & 8.5 & & & 1.1 & & & \\
\hline Epinephelus marginatus & 1.9 & 2.3 & 0.9 & 0.1 & 2.8 & 2.0 & & & & 3.3 & & 20.0 \\
\hline Merluccius merluccius & 0.5 & 1.0 & 41.8 & 54.8 & 26.9 & 52.1 & & 29.2 & 11.9 & 15.4 & 50.0 & 40.0 \\
\hline Mugil cephalus & 28.3 & 13.0 & 2.9 & & & & & & & & & \\
\hline Mullus surmuletus & 4.7 & 5.2 & 6.7 & 11.6 & 8.3 & 13.5 & & 10.4 & 9.0 & 4.7 & & 40.0 \\
\hline Oblada melanura & 5.1 & 2.1 & 1.4 & & & & 10.2 & & & & & \\
\hline Octopus vulgaris & 10.1 & 4.5 & 2.8 & & 9.4 & 0.8 & 3.1 & 36.5 & 0.7 & 2.8 & & \\
\hline Sarpa salpa & 7.1 & 3.6 & 2.0 & & & & 6.1 & & & & & \\
\hline Scomber scombrus & & 6.8 & 2.5 & & 5.0 & 0.2 & & 8.3 & & & & \\
\hline Sepia officinalis & 1.7 & 0.4 & 0.7 & 0.4 & 11.9 & 4.5 & & & 2.0 & 0.5 & 50.0 & \\
\hline Seriola dumerili & 1.1 & 16.7 & 1.5 & & & & 30.6 & & & 66.3 & & \\
\hline Solea solea & & 1.2 & 0.3 & & 14.6 & 6.9 & & & 3.2 & 6.4 & & \\
\hline Sparus aurata & 2.9 & 1.2 & 0.7 & & 3.8 & 0.3 & & 8.3 & & & & \\
\hline Sphyraena sphyraena & & 15.0 & 3.0 & & & & 45.9 & & & & & \\
\hline Trigla lyra & & & 4.4 & 8.5 & & 0.8 & & & & & & \\
\hline Xiphias gladius & & & & & & & & & 72.1 & & & \\
\hline Pagellus erythrinus & & & 15.4 & 21.7 & & 9.0 & & & & & & \\
\hline Other species & 15.3 & 20.7 & 11.3 & 2.8 & 18.1 & 1.6 & 4.1 & 15.6 & 0.0 & 0.5 & 0.0 & 0.0 \\
\hline Number of trials & 4 & 10 & 31 & 24 & 2 & 9 & 1 & 1 & 1 & 1 & 1 & 1 \\
\hline Mean catch per trial & 3.61 & 5.20 & 7.63 & 14.38 & 2.35 & 3.51 & 14.00 & 1.37 & 7.71 & 6.60 & 3.50 & 2.50 \\
\hline SD catch per trial & 4.64 & 5.74 & 12.79 & 13.26 & 1.14 & 6.34 & 16.87 & 1.01 & 23.06 & 16.96 & 0.00 & 0.87 \\
\hline Mean value $(€)$ per trial & 15.7 & 25.4 & 65.2 & 146.4 & 14.0 & 29.4 & 70.0 & 11.7 & 60.7 & 38.7 & 20.0 & 19.6 \\
\hline SD value $(€)$ per trial & 18.8 & 28.9 & 129.3 & 154.0 & 7.0 & 68.1 & 92.7 & 9.6 & 190.8 & 92.5 & 1.2 & 3.0 \\
\hline
\end{tabular}


Table 3. Longlines. Contribution (\%) to the average Bray-Curtis similarity of the SIMPER analysis (Con\%) and species catch composition (\%) and identified by the multivariate analysis on the species catch composition per fishing trials in the south Albanian waters, 2016-2018. Total catch (in kg) and economic return (in €) was also provided per group. Bold values indicated the highest catch and economic values per group.

\begin{tabular}{|c|c|c|c|c|c|c|c|c|c|c|c|c|}
\hline Longlines & Outlier & GrA & GrB & $\mathrm{GrC}$ & GrD & GrE & GrF & GrG & $\mathrm{GrH}$ & Grl & GrK & GrL \\
\hline SIMPER analysis & $100 \%$ & $94.2 \%$ & $98.9 \%$ & $84.0 \%$ & $86.3 \%$ & $71.2 \%$ & $59.6 \%$ & $77.3 \%$ & $77.3 \%$ & $73.7 \%$ & $81.7 \%$ & $82.8 \%$ \\
\hline Diplodus cervinus & & & & & & 51.7 & 29.4 & & & 11.3 & 20.9 & 55.5 \\
\hline Diplodus sargus & & & & & 25.7 & & 48.2 & 18.3 & 26.3 & 24.5 & & \\
\hline Epinephelus marginatus & & & & & 69.1 & 39.3 & & & & 29.0 & & \\
\hline Pagrus pagrus & & & & & & & & & 38.8 & 19.7 & 79.1 & 35.1 \\
\hline Sparus aurata & & & & & & & 22.5 & 75.1 & 30.9 & 15.6 & & \\
\hline Thunnus thynnus & 100 & 25.4 & & 50.4 & & & & & & & & \\
\hline Xiphias gladius & & 74.6 & 100 & 49.00 & & & & & & & & \\
\hline \multicolumn{13}{|l|}{ Species composition (\%) } \\
\hline Diplodus cervinus & & & & & 4.2 & 47.3 & 22.5 & 7.8 & 6.8 & 8.0 & 8.8 & 61.0 \\
\hline Diplodus sargus & & & & 0.7 & 18.0 & 3.0 & 47.3 & 19.3 & 23.9 & 24.0 & 5.1 & 15.3 \\
\hline Epinephelus marginatus & & & & 1.0 & 77.8 & 32.9 & 12.0 & & & 28.5 & & \\
\hline Pagrus pagrus & & & & 1.0 & & 6.0 & 6.0 & & 40.0 & 24.6 & 83.9 & 23.7 \\
\hline Sparus aurata & & & & & & 10.8 & 12.3 & 72.9 & 29.4 & 14.9 & 2.2 & \\
\hline Thunnus thynnus & 100.0 & 12.3 & & 46.3 & & & & & & & & \\
\hline Xiphias gladius & & 87.7 & 99.8 & 50.6 & & & & & & & & \\
\hline Number of trials & 4 & 7 & 15 & 18 & 3 & 3 & 6 & 5 & 37 & 56 & 3 & 3 \\
\hline Mean catch per trial & 121.07 & 90.44 & 32.22 & 2.09 & 1.67 & 1.67 & 1.60 & 2.18 & 2.56 & 3.41 & 1.48 & 79.50 \\
\hline SD catch per trial & 129.56 & 95.53 & 30.53 & 2.03 & 0.98 & 1.28 & 1.52 & 2.21 & 2.42 & 3.92 & 1.12 & 35.11 \\
\hline Mean value $(€)$ per trial & 1041.7 & 785.1 & 274.9 & 24.3 & 11.1 & 19.9 & 14.7 & 46.8 & 48.0 & 99.4 & 12.5 & 318.7 \\
\hline SD value $(€)$ per trial & 1055.5 & 767.4 & 311.5 & 27.8 & 21.9 & 23.9 & 18.5 & 38.9 & 41.6 & 81.0 & 23.4 & 833.2 \\
\hline
\end{tabular}

Mullus surmuletus, Boops boops, Trigla lyra, Sphyraena sphyraena, Octopus vulgaris and Scorpaena scrofa; Table 1). In contrast, Group D comprised the highest catches of the highly-priced species $P$. erythrinus and the moderately priced M. merluccius and T. lyra (Tables 2, 4). Groups B and $\mathrm{F}$ comprised moderate catch, income and fishing activity (Table 2). Catches from Group B (targeted Seriola dumerili, S. sphyraena and Diplodus sargus) peaked during spring, whereas those of Group F (targeted M. surmuletus and Dentex dentex) in March and during July-January (Fig. 2). For both groups, nets with mesh sizes ranging from 22 to $36 \mathrm{~mm}$ were used, operated in shallow and intermediate waters $(0-80 \mathrm{~m})$, and in deep waters $(400 \mathrm{~m})$, respectively (Table 4). Groups A to E and the outliers exhibited a monthly-specific opportunistic tactic (Fig. 2) with low fishing activity, catches and values (Tables 2, 4).

For the longlines, Groups A, B and C comprised high catch and income métiers (cumulatively contributed $77.7 \%$ and $67.1 \%$ of the total catches and values, respectively) with low fishing activity (Tables 3 and 4). They all targeted highly-priced species comprised of the large pelagics Thunnus thynnus and Xiplias gladius, and to a lesser extent of Diplodus sargus, E. marginatus and Pagrus pagrus. Catches from Group A peaked in autumn, whereas Groups $B$ and $C$ extended to more seasons, autumn, in April and August (Fig. 2). Groups $\mathrm{H}$ and I comprised high fishing activity tactics (Table 4) with a moderate representation of both catches and values ( $15.5 \%$ and $18.2 \%$ of the total catches and values, respectively), peaked during spring (41.1\% and $40.0 \%$, respectively) (Figure 2) and targeted highly-priced Sparidae (i.e. Pagrus pagrus, Sparus aurata and Diplodus sargus; Table 1) and Epinephelus marginatus. The rest of the groups (i.e. Groups D, E, F, G, K and $\mathrm{L}$ ) comprised low catch but high-income (cumulatively contributed almost $2 \%$ and $14 \%$ to the total catches and economic value, respectively) multi-species métiers with different targeted species exhibited for each group: (a) Group $D$ targeted $E$. marginatus and to a minor extent D. sargus, (b) Group E targeted Diplodus cervinus and $E$. marginatus, and to a lesser extent $S$. aurata and $P$. pagrus, (c) Group $F$ targeted $D$. sargus, (d) Group G targeted $S$. aurata, (e) Group K targeted P. pagrus and (f) Group L targeted $D$. cervinus. They all exhibited monthly activity with the catches of certain groups that peaked during spring (i.e. Groups D, E, K, L), or in two different seasons (i.e. Group F in May and August; and Group G during JuneJuly) (Fig. 2).

\section{DISCUSSION}

Small-scale fisheries in Mediterranean waters are diverse and complex with numerous landed species that varied 
Table 4. Description of the métiers according to the characteristics of the fishing operations included in each cluster groups (GR) and outliers (Out). Each métier is described through the target species (main and bycatch), vessel (length in $\mathrm{m}$ and engine horsepower in $\mathrm{HP}$ ), gear (length in $\mathrm{m}$, size in $\mathrm{mm}$ ) and fishing operation (distance from shore/fishing depth, fishing duration, \% contribution of whole fishing operations observed) characteristics, as well as the percentage contribution to total annual catch and revenue in the south Albanian waters, 2016-2018. Bold values indicated the three highest catch and economic values per group. GNS, gillnets and LLS, set longlines.

\begin{tabular}{|c|c|c|c|c|c|c|c|c|c|c|c|}
\hline Targeted species & Groups & $\begin{array}{l}\text { Num of } \\
\text { vessels }\end{array}$ & $\begin{array}{l}\text { Vessel } \\
\text { length }\end{array}$ & $\begin{array}{r}\text { Vessel } \\
\mathrm{HP}\end{array}$ & $\begin{array}{r}\text { Gear } \\
\text { length }(\mathrm{m})\end{array}$ & $\begin{array}{r}\text { Gear } \\
\text { size }(\mathrm{mm})\end{array}$ & $\begin{array}{r}\text { Shore } \\
\text { distance/ } \\
\text { depth }(m)\end{array}$ & $\begin{array}{r}\text { Fishing } \\
\text { hours }\end{array}$ & $\begin{array}{l}\% \text { of } \\
\text { trips }\end{array}$ & $\begin{array}{r}\% \text { of } \\
\text { total } \\
\text { catches }\end{array}$ & $\begin{array}{c}\% \text { of } \\
\text { total } \\
\text { value }\end{array}$ \\
\hline \multicolumn{12}{|c|}{ Nets } \\
\hline $\begin{array}{l}\text { B. boops/M. cephalus/O. melanura/ } \\
\text { O. vulgaris }\end{array}$ & GrA & 1 & 5 & 20 & 1500 & $22-36$ & $0-80$ & 12 & 4.7 & 1.99 & 1.02 \\
\hline S. dumerili/S. sphyraena & GrB & 1 & 5 & 20 & 1500 & $22-36$ & $0-80$ & 12 & 11.6 & 7.95 & 4.59 \\
\hline M. merluccius/P. erythrinus & $\mathrm{GrC}$ & 5 & $5-15$ & $20-380$ & $1200-3000$ & $22-36$ & $0-400$ & 12 & 36.0 & 58.33 & 58.88 \\
\hline $\begin{array}{l}\text { M. merluccius/P. erythrinus/M. } \\
\text { surmuletus/T. lyra }\end{array}$ & GrD & 6 & $8.5-15$ & $24-380$ & $1200-3000$ & $23.5-30$ & $50-400$ & $6-15$ & 27.9 & 24.39 & 29.35 \\
\hline M. merluccius/S. officinalis/S. solea/ & GrE & 5 & $6-13$ & $40-125$ & $1200-2000$ & $23.5-30$ & $50-200$ & $6-15$ & 2.3 & 0.85 & 0.60 \\
\hline M. merluccius/M. surmuletus & GrF & 8 & $6-15$ & $24-380$ & $1200-3000$ & $23.5-30$ & $50-400$ & $5-8$ & 10.5 & 2.61 & 2.58 \\
\hline S. sphyraena/S. dumerili & Out 1 & 1 & 5 & 20 & 1500 & $22-36$ & 40 & $5-15$ & 1.2 & 1.04 & 0.61 \\
\hline O. vulgaris/M. merluccius & Out 2 & 1 & 6 & 40 & $600-1000$ & $24-30$ & $50-70$ & 6 & 1.2 & 0.10 & 0.10 \\
\hline$X$. gladius & Out 3 & 1 & 9 & 24 & $1500-2000$ & $26-30$ & 70 & 4 & 1.2 & 1.47 & 1.37 \\
\hline S. dumerili/M. merluccius & Out 4 & 1 & 6 & 40 & $600-1000$ & $24-30$ & 70 & 5 & 1.2 & 1.12 & 0.78 \\
\hline M. merluccius/S. officinalis & Out 5 & 1 & 13 & 125 & $1500-2000$ & $26-30$ & $70-100$ & 6 & 1.2 & 0.07 & 0.05 \\
\hline M. merluccius/M. surmuletus & Out 6 & 1 & 6 & 40 & $600-1000$ & $24-30$ & $50-80$ & 5 & 1.2 & 0.08 & 0.07 \\
\hline \multicolumn{12}{|c|}{ Longlines } \\
\hline T. thynnus & Out & 2 & $3.5-4.6$ & $15-25$ & $4000-10000$ & 3 & $1-3 \mathrm{mi}$ & 4.0 & 2.5 & 4.89 & 23.48 \\
\hline T. thynnus/X. gladius & GrA & 2 & $3.5-4.6$ & $15-25$ & $4000-10000$ & 3 & $1-3 \mathrm{mi}$ & 4.0 & 4.4 & 27.9 & 20.49 \\
\hline X. gladius/ & GrB & 2 & $3.5-4.6$ & $15-25$ & $3800-10000$ & $3,9 \& 12$ & $1-3 \mathrm{mi} \& 2-85$ & 4.0 & 9.4 & 25.01 & 23.10 \\
\hline T. thynnus/X. gladius & $\mathrm{GrC}$ & 2 & $3.5-4.6$ & $15-25$ & $3800-10000$ & $3,9,12 \& 13$ & $1-3 \mathrm{mi} \& 2-85$ & $3-4$ & 11.3 & 24.75 & 0.33 \\
\hline E. marginatus & GrD & 2 & $3.5-4.6$ & $15-25$ & $3800-4200$ & $9,12 \& 13$ & $2-50$ & $2-3$ & 1.9 & 0.26 & 0.32 \\
\hline D. cervinus/E. marginatus & GrE & 2 & $3.5-4.6$ & $15-25$ & $3800-4200$ & $9,12 \& 13$ & $20-25$ & $2-3$ & 1.9 & 0.26 & 0.71 \\
\hline D. cervinus/D. sargus/E. marginatus & GrF & 2 & $3.5-4.6$ & $15-25$ & $3800-4200$ & $9,12 \& 13$ & $20-35$ & $2-5$ & 3.8 & 0.51 & 0.33 \\
\hline S. aurata & GrG & 1 & 4.6 & 25 & 3800 & $9 \& 12$ & 30 & 4 & 3.1 & 0.29 & 7.84 \\
\hline P. pagrus/S. aurata/D. sargus & $\mathrm{GrH}$ & 2 & $3.5-4.6$ & $15-25$ & $3800-4200$ & $9,12 \& 13$ & $2-85$ & $2-5$ & 23.1 & 4.55 & 17.21 \\
\hline D. sargus/E. marginatus & $\mathrm{Grl}$ & 2 & $3.5-4.6$ & $15-25$ & $3800-4200$ & $9,12 \& 13$ & $20-50$ & $2-5$ & 35.0 & 10.98 & 0.96 \\
\hline P. pagrus & GrK & 2 & $3.5-4.6$ & $15-25$ & $3800-4200$ & $9,12 \& 13$ & $25-35$ & $3-5$ & 1.9 & 0.42 & 0.28 \\
\hline D. cervinus & GrL & 2 & $3.5-4.6$ & $15-25$ & $3800-4200$ & $9,12 \& 13$ & $25-35$ & $3-5$ & 1.9 & 0.18 & 4.94 \\
\hline
\end{tabular}

seasonally and the fishing activity performed with different fishing gear, which can be very dynamic through space and time (Lloret et al., 2018). Nets and longlines are commonly used and have a number of different technical characteristics (i.e. mesh sizes, materials, dimensions, trap shape, etc.). Given the variety of habitats and the target species' life cycles, SSFs are characterized by clear seasonality and fishing tactics have been adapted in the space and time dimensions (Roditi et al., 2020). Fishing tactics and strategies could be defined as the combination of extrinsic (environmental conditions and management regulations) and intrinsic factors (technical characteristics of vessels and gear) (Pet-Soede et al., 2001). Tactics are individual actions adopted by an individual fisher, and their succession in time can constitute a strategy.

In the present study, monthly samplings covered $25 \%$ of the total number of small-scale vessels with a high number of fishing trials for vessels using nets and longlines (Moutopoulos et al., 2015). Given that fishing operations were conducted by fishers following traditional practices in traditional fishing grounds and that a wide range of mesh sizes of nets were used (from 22 to $36 \mathrm{~mm}$ ), groupings adopted by fishers were considered as indications of fishing strategies in order to take advantage of the seasonal migrations and availability of the most important target species in each area. Results showed that in the multispecies net fishery ( 16 species contributed up to $94 \%$ of the total catch), target species can be defined 
as the species belonging to a big part of cluster groups of fishing trips for which its relative contribution to the catch is very high (Stergiou et al., 2003; Moutopoulos et al., 2014). The advantage of hierarchical clustering, when compared with other methods (Principal Component Analysis, Principal Coordination Analysis), is that it is based on subjective criteria (e.g., Biseau, 1998; Deporte et al., 2012).

SSFs in Albanian waters exhibited a diversification of fishing tactics, similar to other Mediterranean small-scale fisheries (Tzanatos et al., 2020; Forcada et al., 2010; Grati et al., 2018) triggered by changing conditions in terms of both environmental and market variability, and the availability of the resources. Cluster analyses indicated that the fishing gear (and, to a lesser extent, season and/or depth) strongly affects fishing tactics. The number of the species caught by nets was much higher than by longlines (27 vs. 8), which was attributed to the wide selection range of nets compared to the longlines (Stergiou and Erzini, 2002), and resembling in many instances trawl cod-ends (Stergiou et al., 1996). The diversity in the number of species caught among the different fishing trials might be attributed to the use of gillnets or trammel nets, with the latter exhibiting a wider species selectivity in Mediterranean waters (Greece, Spain and Portugal: Stergiou et al., 2006; Italy: Lucchetti et al., 2020). Given also that there are multiple mesh sizes and net lengths used in each fishing trial, depth and season were the remaining known factors affecting grouping formation that revealed targeted species.

The most consistent fishing tactics followed by fishers using nets were derived from Groups $C$ and D (Table 2), represented by the highly-priced $P$. erythrinus and the moderately-priced $M$. merluccius and $T$. lyra, whereas a wide variety of species with low representation ensured small but persistent production and income (more than $80 \%$ of both total catch and value; Tables 1 and 3). A similar tactic has been also observed in the adjacent Patraikos Gulf (Métier Tr1; Table 1 in Tzanatos et al., 2006). Other significant fishing tactics, in terms of catches, were the two adjacent groups in the cluster positioning, $A$ and $B$, both of which were operated up to $80 \mathrm{~m}$ at a close distance from the shore and targeted $B$. boops and $M$. cephalus, $O$. vulgaris and Sphyraena sphyraena, respectively. Net métier targeting $M$. surmuletus, as well as S. officinalis (Groups $\mathrm{E}$ and $\mathrm{F}$ ), are also documented along the Mediterranean coasts (Algarve-Portugal: Pereira et al., 2019; Gulf of Barcelona: Maynou et al., 2011; Balearic Islands: Maynou et al., 2013; Tabarca Marine Reservewestern Mediterranean Sea: Forcada et al., 2010; Gulf of Gabes: Jabeur et al., 2000; Patraikos Gulf-Ionian Sea: Tzanatos et al., 2006; Cyclades-Aegean Sea: Stergiou et al., 2006; Dodecanese-Levantine Sea: Roditi and Vafidis, 2019). S. solea (high in Group E) was also targeted by Mediterranean fisheries (Portugal: Batista et al., 2009) and landed together with the cephalopods $O$. vulgaris and S. officinalis (Teixeira et al., 2011), which is also confirmed in our study (Table 1).

Multivariate analysis on longline fishing trials revealed two distinct fishing métiers with high catches and economic revenue, the one using drifting longlines targeting the large pelagics $T$. thynnus and $X$. gladius (Groups $A$ to $C$ and outlier; Tables 3,4$)$ and the other using medium-sized hooks (Nos 9 to 13) targeting a wide range of Sparidae species and E. marginatus (Groups $\mathrm{H}$ and I; Tables 3, 4). The vessel size was independent of the fishing strategy due to the narrow size of the fleet involved in longline fishery in the study area (3.5-4.6 m). The métier identified should only be identified as the combination of the target species/month combination. An almost similar number of longline métiers (10) have also been confirmed by Roditi et al. (2020) in Dodecanese Island in the southern Aegean. Likewise, Tzanatos et al. (2006) identified three groups of set longline métiers targeting $S$. dumerili, $D$. dentex, E. guaza and $M$. merluccius. The different métiers were recognized in other areas of the Mediterranean basin (for longlines: Tzanatos et al., 2006; Roditi et al., 2020; for nets: Batista et al., 2009; Roditi and Vafidis, 2019), underlining that the target species are linked to the different environmental features of the place where the longline fishery operated.

Our results also revealed that small-scale fishery exhibited a clear seasonality of catches with species being targeted during high demand for fish (March-May for nets and March-October for longlines; Fig. 2). The seasonality pattern observed in the studied fishing tactics might be also due to the unfavorable weather conditions that occurred during winter which impede the small-sized fishing vessels to exploit the more distant and productive fishing grounds (Thoya and Daw, 2019). This pattern is in agreement with other Adriatic SSFs that mainly operate in areas that can be reached within a few hours from the home port (Bastardie et al., 2017) and are active fully or part-time throughout the year (Matić-Skoko et al., 2017; Grati et al., 2018).

Seeking the maximization of profit based on prior experience, a fisher is switching between alternative tactics during short-term periods in order to take advantage of the availability of the target species and market demands. For instance, the fisher synchronizes its tactic in accordance with the behavior and availability of commercial species, as for example in the case of the spawning season of the targeted species. In fact, monthly catches for the top target species M. merluccius (Groups $\mathrm{C}$ to $\mathrm{F}$ ) peaked from February to March, which coincides with its spawning period in the central Adriatic (Arneri and Morales-Nin, 2005). Likewise, the maximum daily fishing catches for the other target species caught (i.e. $P$. erythrinus, M. surmuletus, B. boops and T. lyra) coincided with their spawning season during spring-summer (Tsikliras et al., 2010). Fishers are experienced in feeding and reproductive behavior of the target species, even though they are not always aware of their reproduction cycle (Moutopoulos et al., 2014). 
Non-targeted species (species of economic category B and C; Table 1), mostly included in the outlier and less important groups of fishing trials (Tables 2, 4), were implying an opportunistic tactic during a short-term period. These species represented up to $15 \%$ of the total catch and economic value of the net fishery, contributed as by-catch species (incidentally caught species) that were occasionally caught (each with more than $1 \%$ to the total net catches), ensuring a low, but additional income to the fishermen from species other than the targeted ones, safeguarding stability in total landings and, thus, in economic returns throughout the year (Forcada et al., 2010; Moutopoulos et al., 2014).

Prioritizing market demands, small-scale fishers might adopt a "higher income-higher risk" tactic by targeting species of high commercial value during a specific shortterm period of the year. These were the cases of $T$. thynnus métier in longlines in May (23.5\% of the longline economic return; Table 4) and of $X$. gladius and S. dumerili in nets in August and October, respectively (outliers 3 and 4; Table 2). Such tactics proved to be quite efficient in terms of daily income and they might imply the net economic gain of the fisher by targeting species of high commercial value during a period of high demand for fish species due to tourism, but in parallel seemed to increase the risk as indicated by the higher variability of both fisheries catches and economic revenue (SD estimates in Tables 2, 3 for nets and longlines).

\section{CONCLUSION}

The present study aims to improve the monitoring of the fisheries data in an area where adequate fisheries statistics is still one of the main constraints (Grati et al., 2018). Taking into account that nowadays fisheries management is becoming more multi-disciplinary, there is an urgent need to have robust monitoring mechanisms and multiple control protocols. Fisheries monitoring based on fishing strategies per fishing gear (Tserpes et al., 2006; Tzanatos et al., 2013) might contribute towards more effective calculation of the nominal fishing effort measurements and reduce data uncertainty.

Given that some of the most representative species caught by the small-scale gear in the study area (i.e. $M$. merluccius, $M$. surmuletus and T. lyra) are also exploited by trawls (Moutopoulos et al., 2015) at a great range of fishing depths (up to $400 \mathrm{~m}$ ), their essential habitats are continuously subjected to fishing and, thus, allowing no spatial and/or temporal refuge for different stocks. The problem gets aggravated by taking into account that numerous species caught in the present study (30), which exhibited different life-history characteristics, are constantly presented in the fishing grounds, albeit at lower abundances than target species, which resulted in an increased diversity of landings. This makes the application of the single-based management approach optimal for some species, but totally ineffective for others
(Stergiou et al., 2009) and, thus, management should be complemented with multi-species approaches such as ecosystem-based measures, which protects many species at a time (Stergiou, 2002).

\section{ACKNOWLEDGEMENT}

The authors would like to thank the Sarandë and Himara small-scale fishers for their valuable help in the fieldwork.

Nedostatak pouzdanih statističkih podataka o ribarstvu sprječava potpunu procjenu stanja morskih resursa. Središte ovog problema su područja siromašna podacima o ribarstvu, kao što je morsko područje uz obalu Albanije, a posebno područje malog ribolova. Cilj ovog istraživanje je prikazati mali ribolov u vodama južne Albanije na temelju dnevnog praćenja ulova ribarskih vrsta tijekom dvogodišnjeg razdoblja (2016.-2018.). Rezultatima je utvrđeno ukupno 6, odnosno 11 ribolovnih métiera za mreže i parangale. Najvažnije ciljne vrste za mreže u smislu ulova bile su Merluccius merluccius, Mullus surmuletus, Pagellus erythrinus, Sepia officinalis i Solea vulgaris. Ribolov s parangalom kategoriziran je u dva različita ribolovna područja, jedan je usmjeren na velike pelagične vrste Thunnus thynnus i Xiphias gladius, a drugi za širok raspon vrsta Sparidae i Epinephelus marginatus. Ovdje predstavljeni podaci i analize imaju za cilj smanjiti trenutni nedostatak kvantitativnih podataka u slučaju ograničenih podataka o ribarstvu, kao što je albanski mali ribolov, te pružiti informacije za razvoj praćenja ovog ribarstva.

Keywords: métier, sastav vrsta, Jadransko more

\section{REFERENCES}

Anderson, M. J., Gorley, R. N., Clarke, K. R. (2008) PERMANOVA+ for PRIMER: Guide to Software and Statistical Methods. PRIMER-E: Plymouth, UK.

Arneri, E., Morales-Nin, B. (2005) Aspects of the early life history of European hake from the central Adriatic. Journal of Fish Biology, 56(6), $1368-1380$.

Bakiu, R., Cakalli, M., Korro, K., di Franco, A., Guidetti, P. (2018) Small-Scale Fisheries at an Albanian Marine Protected Area: A Collaborative Attitude is Associated with Higher Catches Marine and Coastal Fisheries Dynamics. Marine Coastal Fisheries, 10(6), 527-535.

Bakiu, R., Gurma, M. (2018) Characterization of small-scale and large-scale fisheries in Sarandë (South Albania, Ionian Sea). Journal of Black Sea/Mediterranean Environment, 24(3), 212-223.

Bastardie, F., Angelini, S., Bolognini, L., Fuga, F., Manfredi, M. (2017) Spatial planning for fisheries in the Northern Adriatic: working towards viable and sustainable fishing. Ecosphere, 8(2), :e01696.

Batista, M. I., Teixeira, C. M., Cabral, H. N. (2009) Catches of target species and bycatches of an artisanal fishery: the case of a trammel net fishery in the Portuguese 
coast. Fisheries Research, 100, :167-177.

Biseau, A. (1998) Definition of a directed fishing effort in a mixed-species trawl fishery, and its impact on stock assessments. Aquatic Living Resources, 11(3), 119-136.

Bray, J. R., Curtis, J. T. (1957) An ordination of the upland forest communities of southern Wisconsin. Ecological Monography, 27, 325-349.

Carpi, P., Scarcella, G., Cardinale, M. (2017) The Saga of the Management of Fisheries in the Adriatic Sea: History, Flaws, Difficulties, and Successes toward the Application of the Common Fisheries Policy in the Mediterranean. Frontiers in Marine Science, 22 December 2017.

Clarke, K. R., Warwick, R. M. (2001) Change in Marine Communities: An Approach to Statistical Analysis and Interpretation. PRIMER-E. $2^{\text {nd }}$ edition. Plymouth, UK.

Çobani, M. (2005) Small-scale fisheries in Albania. In Adriatic Sea Small-scale Fisheries. Report of the AdriaMed Technical Consultation on Adriatic Sea Small-Scale Fisheries, p. 13-21, Split, Croatia, $14^{\text {th }}-15^{\text {th }}$ October 2003. FAO-MiPAF Scientific Cooperation to Support Responsible Fisheries in the Adriatic Sea. GCP/ RER/010/ITA/TD15. AdriaMed Technical Documents, 15.

Deporte, N., Urlich, C., Mahévas, S., Demanénce, S., Bastardie, F. (2012) Regional métier definition: a comparative investigation of statistical methods using a workflow applied to international otter trawl fisheries in the North Sea. ICES Journal of Marine Science, 69(2), 331-342.

FAO, (2020) The State of Mediterranean and Black Sea Fisheries 2020. General Fisheries Commission for the Mediterranean. Rome. 172 p.

Field, J. G., Clark, K. R., Warwick, R. M. (1982) A practical strategy for analysing multispecies distribution patterns. Marine Ecology Progress Series, 8, 37-52.

Forcada, A., Valle, C., Sánchez-Lizaso, J. L., Bayle-Sempere, J. T., Corsi, F. (2010) Structure and spatio-temporal dynamics of artisanal fisheries around a Mediterranean marine protected area. ICES Journal of Marine Science, 67, 191-203.

Grati, F., Aladžuz, A., Azzuro, E., Bolognini, L., Carbonara, P., Çobani, M., Domenichetti, F., Dragičević, B., Dulčić, J., Molone, N. (2018) Seasonal dynamics of small-scale fisheries in the Adriatic Sea. Mediterranean Marine Science, 19(1), 21-35.

Jabeur, C., Gobert, B., Missaoui, H. (2000) Typology of the small-scale fleet in the Gulf of Gabes (Tunisia). Aquatic Living Resources, 13(6), 421-428.

Lloret, J., Cow, I. G., Cabral, H., Castro, M., Font, T., Gonçalves, J. M. S., Gordoa, A., Hoefnagel, E., Erzini, K. (2018) Small-scale coastal fisheries in European Seas are not what they were: ecological, social and economic changes. Marine Policy, 98, 176-186..

Lucchetti, A., Virgili, M., Petetta, A., Sartor, P. (2020) An overview of gill net and trammel net size selectivity in the Mediterranean Sea. Fisheries Research, 230,
105677.

Matić-Skoko, S., Ikica, Z., Vrdoljak, D., Peharda, M., Tutman, P., Dragičević, B., Joksimović, A., Dulčić, J., Peŝič, A. (2017) A comparative approach to the Croatian and Montenegrin small-scale fisheries (SSF) in the coastal eastern Adriatic Sea: fishing gears and target species. Acta Adriatica, 58(3), 459-480.

Maynou, F., Recasens, L., Lombarte, A. (2011) Fishing tactics dynamics of a Mediterranean small-scale coastal fishery. Aquatic Living Resources, 24, 149.

Maynou, F., Morales-Nin, B., Cabanellas-Reboredo, M., Palmer, M., García, E., Grau, A. (2013) Small-scale fishery in the Balearic Islands (W Mediterranean): A socio-economic approach. Fisheries Research, 139, 11-17.

Moore, C., Davie, S., Robert, M., Pawlowski, L., Dolder, P., Lordan, C. (2019) Defining métier for the Celtic Sea mixed fisheries: A multiannual international study of typology. Fisheries Research, 219, 105310.

Moutopoulos, D. K., Brady, B., Pauly, D. (2015) Reconstruction of Albanian fishery catches by fishing gear, 1950 to 2010. Fisheries Centre Working Paper \#2015-12, University of British Columbia, Vancouver, $12 \mathrm{p}$.

Moutopoulos, D. K., Ramfos, A., Moukas, C., Katselis, G. (2014) High frequency on board monitoring from a fully dependent small-scale fisherman in Central Greece (Korinthiakos Gulf). International Aquatic Research, 6, 67.

Pereira, F., Vasconcelos, P., Moreno, A., Gaspar, M. B. (2019) Catches of Sepia officinalis in the small-scale cuttlefish trap fishery off the Algarve coast (southern Portugal). Fisheries Research, 214, 117-125.

Pet-Soede, C., Van Densen, W. L. T., Hiddink, J. G., Kuyl, S., Machiels, M. A. M. (2001) Can fishermen allocate their fishing effort in space and time on the basis of their catch rates? An example from Spermonde Archipelago, SW Sulawesi, Indonesia. Fisheries Management and Ecology, 8, 15-36.

Roditi, K., Antoniadou, C., Matsiori, S., Halkos, G., Vafidis, D. (2020) Longline métiers and associated economic profiles in eastern Mediterranean fisheries: The case study of Kalymnos Island (South Aegean Sea). Ocean and Coastal Management, 195(1), 105275.

Roditi, K., Vafidis, D. (2019) Net Fisheries' Métiers in the Eastern Mediterranean: Insights for Small-Scale Fishery Management on Kalymnos Island. Water, 11, 1509.

Stergiou, K. I. (2002) Overfishing, tropicalization of fish stocks, uncertainty and ecosystem management: resharping Ocham's razor. Fisheries Research, 55(1-3), 1-9.

Stergiou, K. I., Erzini, K. (2002) Comparative fixed gear studies in the Cyclades (Aegean Sea): size selectivity of small-hook longlines and monofilament gill nets. Fisheries Research, 58, 25-40.

Stergiou, K. I., Machias, A., Somarakis, S., Kapantagakis, A. (2003) Can we define target species in Mediterranean 
trawl fisheries? Fisheries Research, 59, 431-435.

Stergiou, K. I., Moutopoulos, D. K., Armenis, G. (2009) Perish legally and ecologically: the ineffectiveness of the minimum landing sizes in the Mediterranean Sea. Fish Management and Ecology, 16, 368-375.

Stergiou, K. I., Moutopoulos, D. K., Soriguer, M. C., Puente, E., Lino, P. G., Zabala, C., Monteiro, P., Errazkin, L. A., Erzini, K. (2006) Trammel net catch species composition, catch rates and métiers in southern European waters: a multivariate approach. Fisheries Research, 79, 170182.

Stergiou, K. I., Petrakis, G., Politou, C. -Y. (1996) Smallscale fisheries in the south Euboikos Gulf (Greece): species composition and gear competition. Fisheries Research, 26, 325-336.

Thoya, P., Daw, T. M. (2019) Effects of assets and weather on small-scale coastal fishers' access to space, catches and profits. Fisheries Research, 212, 146-153.

Tserpes, G., Moutopoulos, D. K., Peristeraki, P., Katselis, G., Koutsikopoulos, C. (2006) Study of swordfish fishing dynamics in the eastern Mediterranean by means of machine learning approaches. Fisheries Research, 78(2-3), 196-202.

Tsikliras, A., Antonopoulou, E., Stergiou, K. I. (2010) Spawning period of Mediterranean marine fishes. Reviews in Fish Biology and Fisheries, 20, 499-538.

Tzanatos, E., Georgiadis, M., Peristeraki, P. (2020) Small-
Scale Fisheries in Greece: Status, Problems, and Management. In Pascual-Fernández J, Bavinck M (Eds), Small-Scale Fisheries in Europe: Status, Resilience and Governance. MARE Publication Series, vol 23. Springer, Cham.

Tzanatos, E., Castro, J., Forcada, A., Matić-Skoko, S., Gaspar, M., Koutsikopoulos, C. (2012) A MétierSustainability-Index (MSI25) to evaluate fisheries components: assessment of cases from data-poor fisheries from southern Europe. ICES Journal of Marine Science, 70(1), 78-98.

Tzanatos, E., Dimitriou, E., Papaharisis, L., Roussi, A., Somarakis, S., Koutsikopoulos, C. (2006) Principal socio-economic characteristics of the Greek small-scale coastal fishermen. Ocean and Coastal Management, 49, 511-527.

Teixeira, C. M., Batista, M. I., Cabral, H. N. (2011) Landing profiles and typologies of flatfish fisheries on the Portuguese coast. Aquatic Living Resources, 24, 169182. .

Urlich, C., Wilson, D. C. K., Nielsen, J. R., Bastardie, F., Reeves, S. A., Andersen, B. S., Eigaard, O. R. (2012) Challenges and opportunities for fleet- and métierbased approaches for fisheries management under the European Common Fishery Policy. Ocean and Coastal Management, 70, 38-47. 